\title{
Does Sterilization Policy Exert an Upward Pressure on Interest Rate as Dictated by
} Theory? A Nigerian Example

\author{
Nzeh, Innocent Chile ${ }^{1 \rtimes}$ \\ Nwogwugwu, Uche Collins ${ }^{2}$ (D) \\ Nkamnebe, Ogochukwu Edith ${ }^{3}$ iD \\ Millicent Adanne Eze ${ }^{4}$ (D) \\ Abubakar Yusuf ${ }^{\mathfrak{s}}$ (D) \\ Bartholomew.O.N. Okafor ${ }^{6}$
}
'Department of Economics, Renaissance University Ugbawka, Enugu State, Nigeria.
Email:nzechile@yahoo.com Tel: +234-8034222084
${ }^{2,3}$ Department of Economics, Nnamdi Azikiwe University, Awka, Anambra State, Nigeria.
"Email: uchenwogrwugro@gmail.com Tel: +234- 8037076355"
sEmail: oe_nkamnebe@unizik.edu.ng Tel: +2s4-8022447451
${ }^{4}$ School of Business, Law and Social Sciences, Abertay University, Dundee, United Kingdom.
'Email:ezemillicent@gmail.com Tel: (+44)745945210s
National Metallurgical Development Centre (NMDC) Jos, Plateau State, Nigeria.
${ }^{s}$ Email:bbkr_yusuf2000@yahoo.com Tel: +234-8063001010
${ }^{6}$ Department of Economics, Nile University of Nigeria, Nigeria.
${ }^{6}$ Email:bartholomerv.okafor@yahoo.com Tel: +234-8035884378

Abstract

The implications of capital inflows on the economy and the fallout of the policy geared towards addressing these phenomena, especially the impact of the policy on interest rate, motivated this study. Under the framework of the autoregressive distributed lag (ARDL) technique and using monthly series over the period from 2010:M1 to 2021:M3, the findings show that in the short-run, sterilization policy leads to a rising interest rate in the current period. However, after a lag, sterilization policy depresses the interest rate. It was equally found that, in the long-run, sterilization policy pushes the interest rate up. Also, a negative relationship was observed between money supply and interest rate in both the short-run and the long-run, and the exogenous variables in the model influence the interest rate significantly. We therefore recommend that different measures should be adopted to cushion the effect of unsustainable capital inflows to avoid repeated need for further sterilization and the increasing cost of sterilization in the long run. It is also recommended that exogenous variables should be factored in when determining a desirable interest rate in line with economic reality.

Keywords: Sterilization policy, Monetary policy, Capital inflows, Exchange rate, Interest rate, ARDL.

JEL Classification: E52; F38; F31; B23.

Citation | Nzeh, Innocent Chile; Nwogwugwu, Uche Collins; Nkamnebe, Ogochukwu Edith; Millicent Adanne Eze; Abubakar Yusuf; Bartholomew.O.N. Okafor (2021). Does Sterilization Policy Exert an Upward Pressure on Interest Rate as Dictated by Theory? A Nigerian Example. Asian Journal of Economics and Empirical Research, 8(2): 48-57.

History:

Received: 30 April 2021

Revised: 2 June 2021

Accepted: 23 June 2021

Published: 15 July 2021

Licensed: This work is licensed under a Creative Commons

Attribution 3.0 License $(\mathrm{cc}) \mathbf{E}$

Publisher: Asian Online Journal Publishing Group
Acknowledgement: All authors contributed to the conception and design of the study.

Funding: This study received no specific financial support.

Competing Interests: The authors declare that they have no conflict of interests.

Transparency: The authors confirm that the manuscript is an honest, accurate, and transparent account of the study was reported; that no vital features of the study have tran aritted; and that any discre been omitted; and that any discrepancies from the study as planned have been explained

Ethical: This study followed all ethical practices during writing.

\section{Contents}

1. Background to the Study.

2. Literature Review

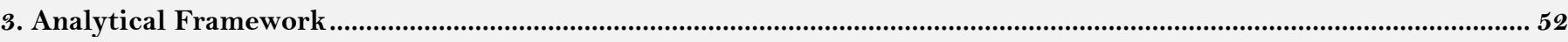

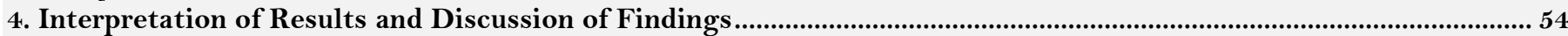

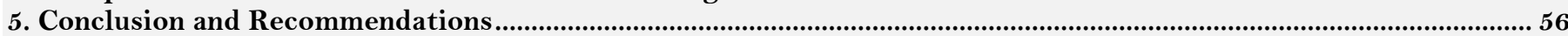

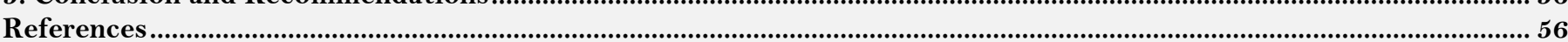




\section{Contribution of this paper to the literature}

This study contributes to the existing literature by exploring whether the implementation of sterilization policy raises domestic interest rates in Nigeria as suggested by theory. This study was conducted by adopting a relevant proxy for sterilization policy, which previous studies did not consider.

\section{Background to the Study}

Capital inflows have become a veritable means of cushioning the effects of a shortfall in revenue, especially for countries that usually experience an adverse balance of payments position. This is mainly the case in most developing countries that are in dire need of additional resources to survive occasional liquidity constraints. The current upsurge in capital inflows in developing countries, observed by Calvo \& Reinhart (1998), is a recent development. The study contended that the nature of capital that flows into the economies of developing countries used to be in the form of official transfers. Several factors have been noted to be responsible for these rising inflows, a major one being the relaxation of impediments to capital mobility across countries. Capital inflows are needed as a way of obtaining additional resources; however, they come with some negative consequences if not well managed. As noted by Lee (1997), rising capital inflows have a tendency to cause an increase in monetary aggregates, which is subject to diverse consequences, such as domestic currency appreciation and rising inflation. This situation arises as the monetary authorities intervene in the reserve accretion through the purchase of foreign exchange. Such practice leads to a rise in the monetary base of the domestic commercial banks, thus giving rise to growth in monetary aggregates.

Capital inflows in Nigeria have been increasing over the years, particularly since the country's discovery of oil in commercial quantities, though with some years of decline. Apart from the proceeds from the oil sector, which has been noted as the major source of liquidity in the country, other sources of capital inflows include, among others, foreign direct investment, foreign portfolio investment, diaspora remittances and growth in external debt. Worthy of note is the recent upsurge in remittances, which accounts for a large share of the country's gross domestic product (GDP). On realizing the importance of diaspora remittances, the Central Bank of Nigeria (CBN), which is the official monetary regulatory authority, has been putting measures in place to attract remittances. Currently, the $\mathrm{CBN}$, in order to shore up remittances, has been offering five naira for every dollar sent from abroad, and consequently, the country's reserves have improved.

From Figure 1 below, it can be seen that there is a rising trend in the sources of capital inflows in Nigeria since the start of the current democratic dispensation in 1999. These sources include official development assistance (ODA), remittances (REM), external debt (Ext. Debt), foreign portfolio investment (FPI) and foreign direct investment (FDI). The consolidation of the banking sector and other reforms put in place around 2005 stimulated investor confidence within this period, thus leading to growth in inflows. Between 2007 and 2008, there was growth in the capital market activities partly due to conducive policies and bullish seasons in the advanced market economies, which trickled down to the domestic economy in the form of investments in the capital market. However, the economic meltdown of 2009 affected the country's capital inflows. Before 2016, external debt was low; however, the regime change in 2015 and this led to a rise in external debt, which pulled up capital inflows.

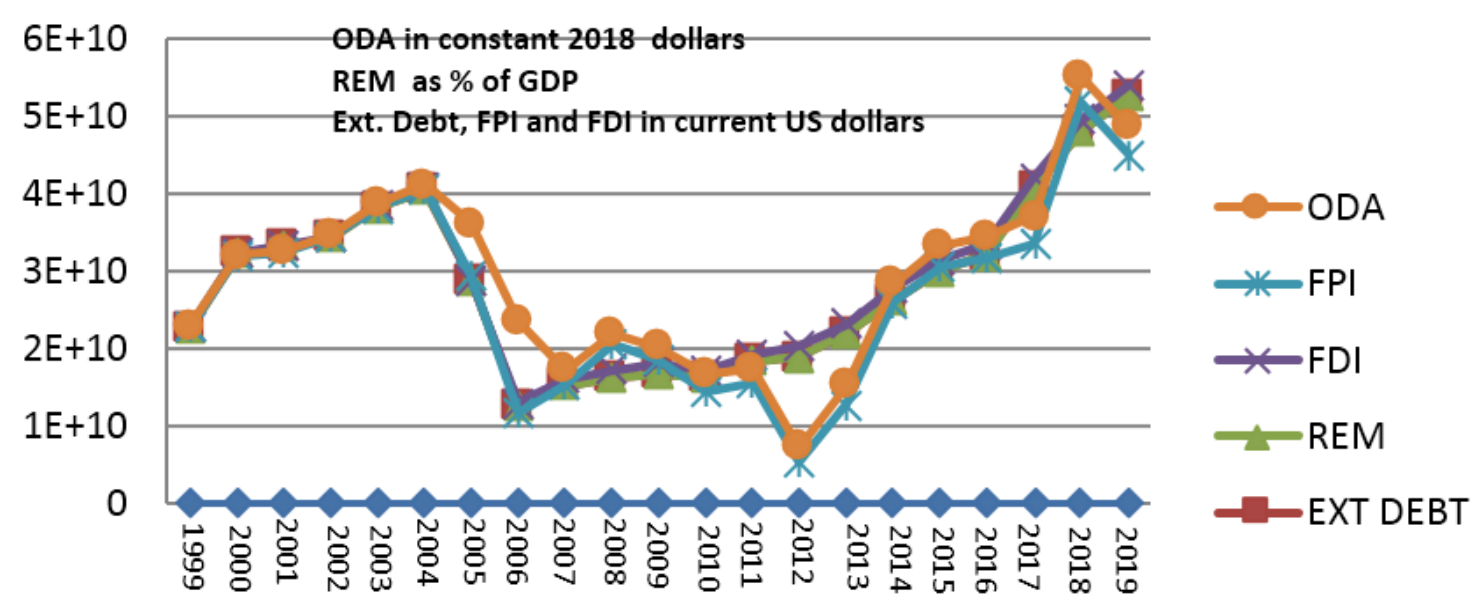

Figure 1. Trend in sources of capital inflows in Nigeria.

Countries witnessing excess and abrupt capital inflows put measures in place to avoid the likely negative consequences associated with the rising domestic money supply that this could trigger. Several measures lead to countries witnessing capital inflows in order to mitigate the monetary effects of this development. Some of these measures include exchange rate intervention, fiscal tightening, transfer of government's deposits from the commercial banking system, and sterilization. Among these measures, sterilization is usually given preference because of its timeliness of implementation and the absence of political interference associated with it. The popularity of sterilization has been noted by Lee (1997) and Reinhart \& Reinhart (1998). The term sterilization refers to measures put in place to neutralize the monetary effect of reserve inflows through the open market sales of domestic securities and increases in reserve requirements (Takagi \& Esaka, 1999).

In Nigeria, the CBN, in order to sterilize systemic liquidity, mainly adopts foreign exchange sales. As a followup to this, the $\mathrm{CBN}$ also issues government bills and bonds in the primary market in addition to influencing the reserve position of commercial banks through change in the cash reserve ratio (CRR). In addition to these, Okpanachi (2013) observed that the CBN uses the repos and exchange rate swaps as well as withdrawal of public sector funds from the deposit money banks to mitigate the impact of rising inflows. In particular, the CBN has been using the open market operation (OMO) consistently as it deliberates the position of the cash reserve ratio in line with the current money supply situation in each of its monthly monetary policy committee meetings.

Operationally, sterilization entails the monetary authorities altering the net domestic assets (NDAs) in order to influence the change in net foreign assets (NFAs). Thus, a rise in NFAs indicates that the monetary authorities 
anticipate a rise in money supply due to foreign exchange intervention. Consequently, the NDAs are reduced to mitigate the effect of the rising money supply. However, the reverse is the case when the NFAs fall. In Figure 2 below, within the 2018-2019 period when capital inflows were high, the CBN engaged in a sterilization exercise as indicated by the reduction in NDAs due to rising NFAs. The band between NFAs and NDAs widens in any period when capital inflows associated with NFAs rise very high.

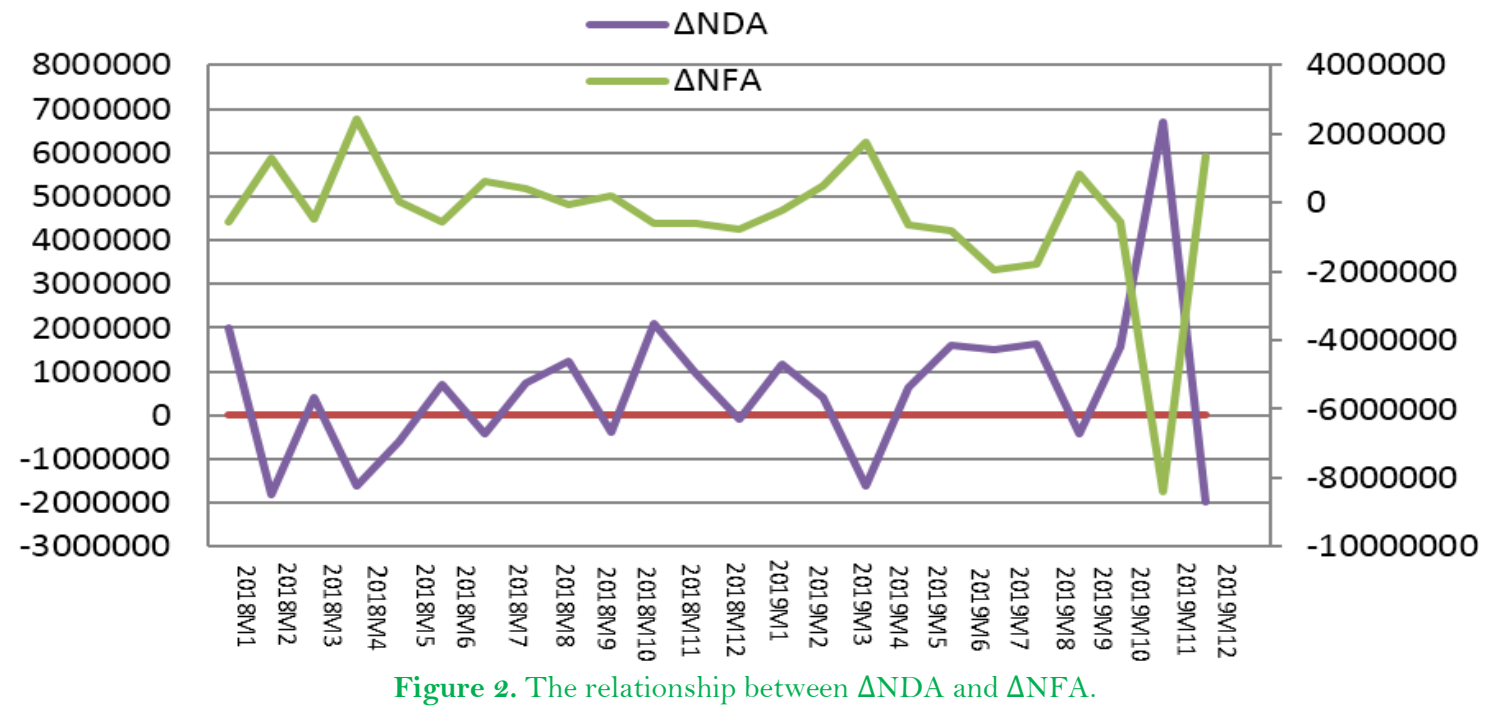

The role of sterilization in neutralizing the monetary impact of capital inflows comes with costs. The limits to the use of sterilization have been noted by Lee (1997) and include the fact that sterilization cannot be effective in the face of increasing capital mobility. The study also observed that sterilization does not work effectively over a longer period if shocks are persistent as it is not designed to handle the underlying causes of shocks. One major fallout of sterilization is that the interest rate differential can widen by reducing the NDA through open market sales of domestic bonds, which leads to a further round of capital inflows. Okpanachi (2013) corroborated this position and contended that sterilization cannot permanently neutralize the risks relating to high and persistent flows. This is partly due to the offsetting decrease in domestic assets that give rise to higher domestic interest rates in relation to foreign rates. Consequently, as noted by Ljubaj, Martinis, \& Mrkalj (2010), the monetary authorities will find themselves in a vicious circle of implementing sterilization policy. Therefore, the potential rise in domestic interest rate as a consequence of implementing sterilization policy motivated this study to investigate if this situation holds empirically and what monetary implications it portends, especially in Nigeria where domestic interest rate is comparatively high.

The choice of a proxy for sterilization policy is further motivation for this study. Previous studies have always used the coefficient of NFA to proxy sterilization policy. It is our view that the argument for using the coefficient of NFA as proxy for sterilization policy can only hold water when investigating the degree of sterilization using the monetary policy reaction function, where any change in NFA is neutralized with a corresponding change in NDA. However, if the objective is finding the impact of sterilization on any monetary policy variable, then the coefficient of NFA as a proxy for sterilization becomes weak. Using NFA to proxy sterilization amounts to investigating the impact of capital inflows on the variable of interest, which defeats the objective of sterilization policy. We thus depart from previous studies by applying total sterilization as a proxy for sterilization policy. The formula for calculating total sterilization was obtained from Lavigne (2008). The benefit of adopting this proxy is that, unlike the coefficient of NFA, it incorporates the two main measures that influence the reserve position of commercial banks, namely the open market operation $(\mathrm{OMO})$ and the cash reserve ratio. As observed by Lavigne (2008), "a measure of the total effects of all sterilization policies should integrate both market-friendly and nonmarket-friendly policies designed to limit domestic money multipliers".

\subsection{Some Stylized Facts}

The aftermath of capital inflows is their influence of the reserve position of the capital recipient country. Nigeria's foreign reserves have been experiencing fluctuations over the years in line with the country's capital inflows. Figure 3 below shows that the country's reserves rose between 2007 and 2008. This was partly due to the high global demand for oil, which resulted in reserve accretion during that period. However, with the onset of the recession around 2008 coupled with the militants' activities in the country's oil-rich Niger Delta region which crippled oil production, reserves began to witness a downward trend, which only started picking up from 2012. The amnesty programme executed by the administration in 2010 , which was used to quell the militancy in the Niger Delta region, led to an improvement in oil production, and this rubbed off on the country's reserves. As observed by Aghalino (2012), the amnesty programme was successful as witnessed in improved oil production and a reduction in bunkering activities in the Niger Delta region. From 2013, the reserve position began to show a rising trend until 2014, partly due to increased oil prices and relatively consistent policy of the administration. As the leadership of the country changed in 2015, the reserve position began to dwindle owing to the delay in the takeoff of the administration, which affected the policy direction and thus eroded investors' confidence. However, the reserves started to improve in 2018 up until 2019, when it experienced a downward trend. Currently, the reserves have depleted in such a way that the government has been urgently attempting to procure external debt to shore up the reserves. 


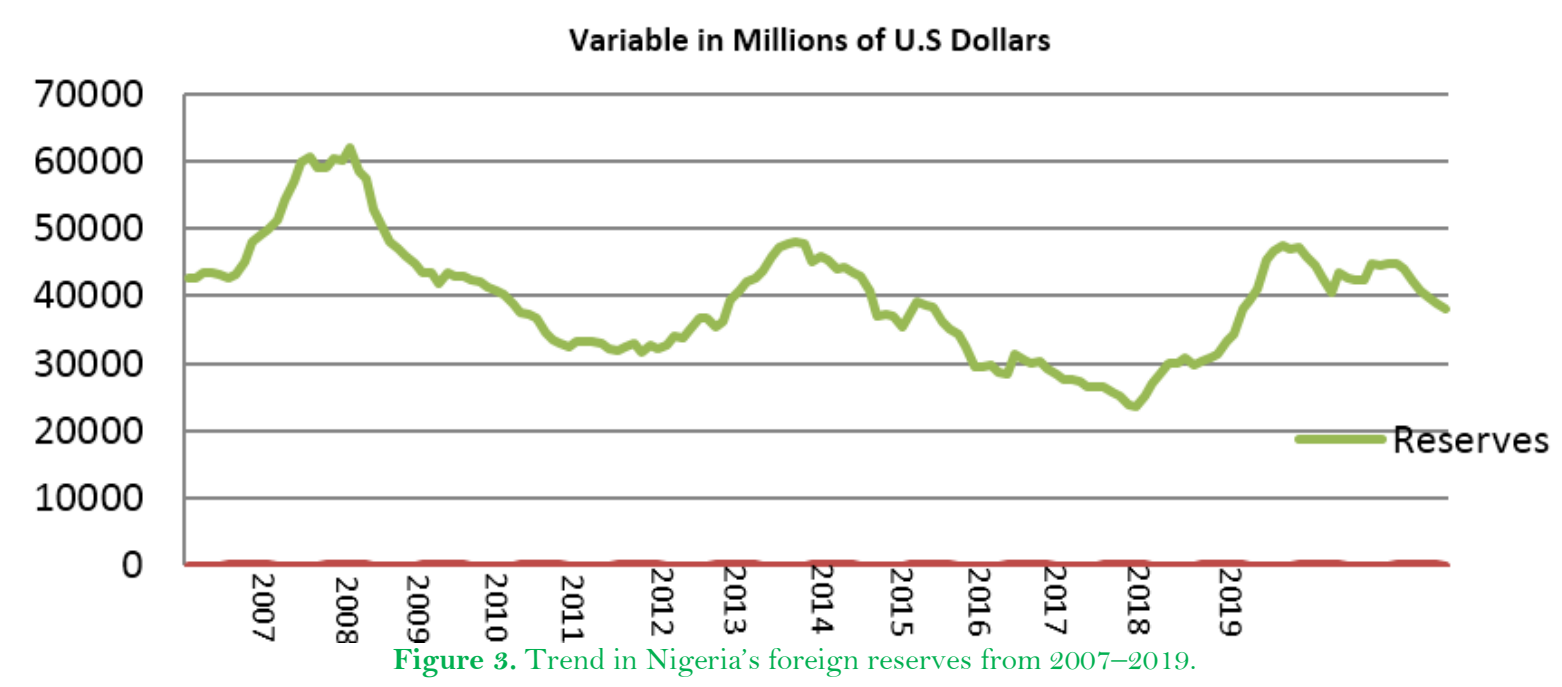

The evidence in Figure 4 shows that the Treasury bill rate rose in 2019 up to around the third quarter, and this growth corresponds with the growth in external reserves. Apart from sterilizing the reserve inflows through the OMO, the government at both the state and federal levels has been floating bonds to raise funds, which led to the rising trend in the Treasury bill rate. Usually, the Treasury bill rates are offered at a rate higher than the market rate. The essence of offering rates higher than the market rate is to make the bond attractive to investors because if foreign rates are more attractive, the subscription rate will be low and that could frustrate the sterilization effort of the monetary authorities. The success of the bond sell through the OMO is expected to neutralize the monetary impact of reserves accumulation. As reserves began to decline around 2020, as depicted in Figure 3 above, the OMO began to slow down as evidenced from the declining trend in the Treasury bill rate.

\section{TBR}

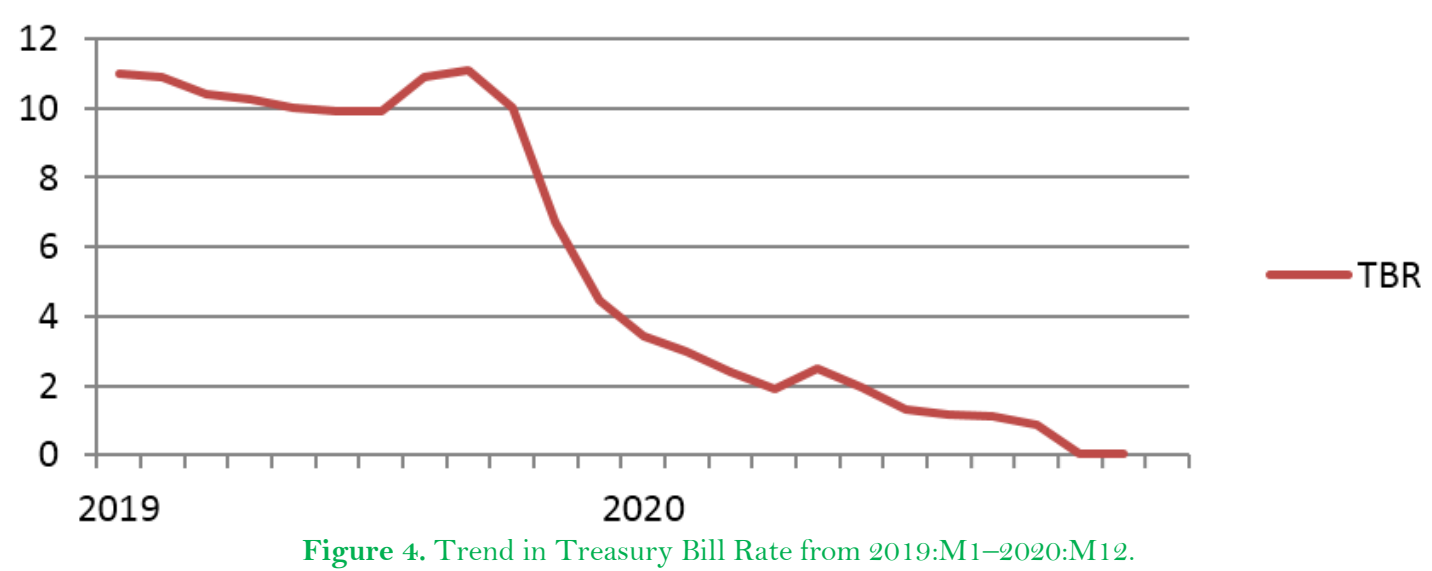

Aizenman \& Glick (2008) contended that reserves accumulation has some monetary implications. The study noted that when the monetary authorities purchase foreign reserve assets, funding arrangements for this policy should be made. The funding could be in the form of increasing the reserve money base or by reducing the net domestic assets. The former choice has the potential of being inflationary, while the later has impact on the domestic reserve money base. Lavigne (2008) noted that when a central bank purchases foreign exchange as a way of neutralizing the domestic currency appreciation, it can issue bonds to the domestic market to dampen the effect of this measure. Accordingly, such a measure uses up the domestic money supply, thus effectively neutralizing its impact on domestic interest rates and inflation. In summary, the intervention of the monetary authorities regarding increasing capital inflows usually leads to an increase in money supply. Figure 5 below shows that since 1999, the broad money supply has been witnessing a rising trend. Consequently, monetary authorities react by using different measures to mitigate the impact of this development on the macroeconomic environment.

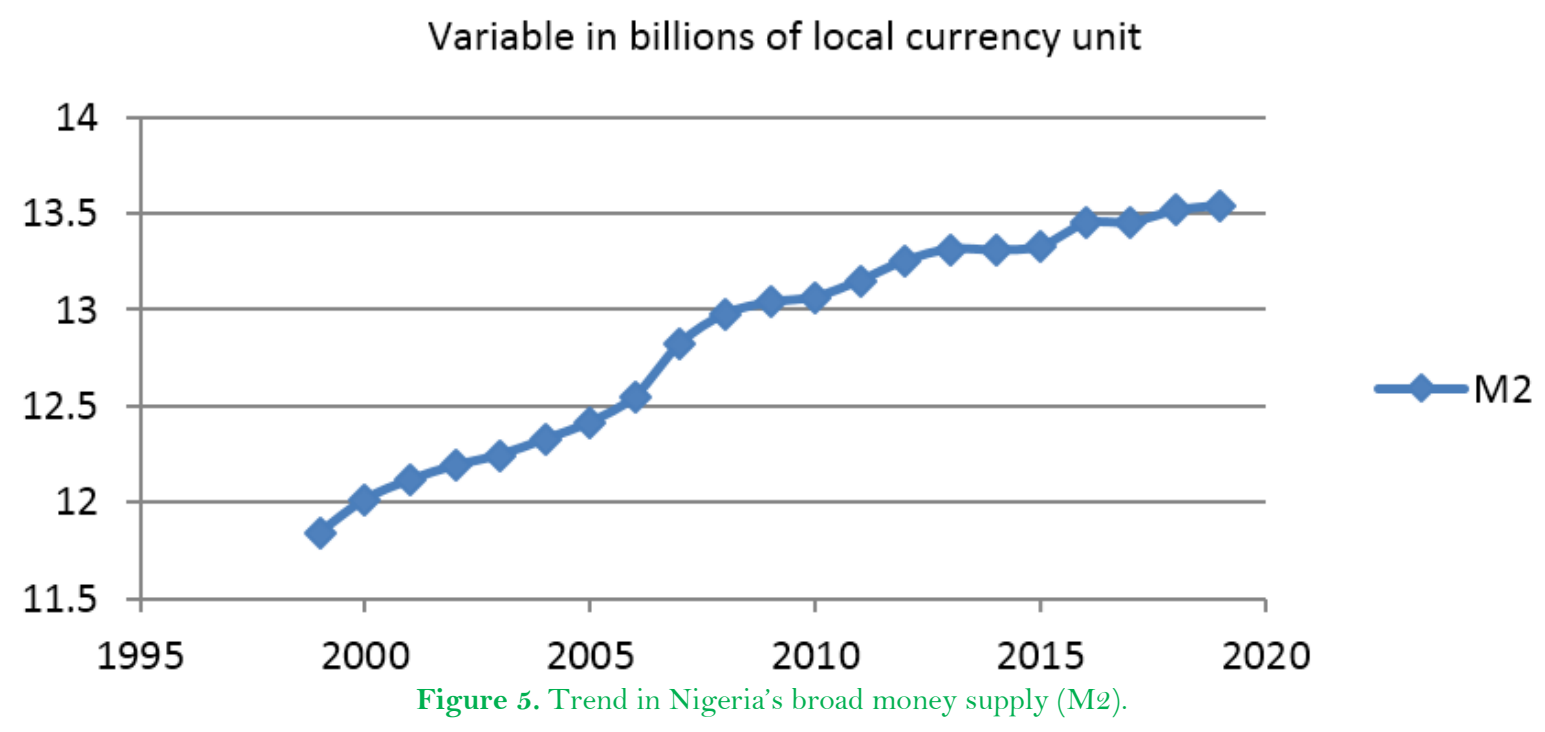




\section{Literature Review}

In this study, we reviewed the basic literature at both country-specific and international levels.

\subsection{Empirical Literature}

The need to mitigate the monetary impact of capital inflows has led to several studies on sterilization across different countries. Using a multivariate dynamic regression and a sample of quarterly data from 28 countries over the period from 1990 to 2010, Bleaney \& Devadas (2013) showed that broad money is sterilized to a significantly smaller degree than reserve money. In a study on Nigeria, Okpanachi (2013) showed that the degree of sterilization is significantly high. However, Chung, Hwang, \& Wang (2014) revealed that Chinese monetary authorities sterilize almost all of the effects of international capital inflows, and this study is in line with previous studies on China. Using the vector autoregressive (VAR) model, Blanchard, Adler, \& De Carvalho Filho (2015) revealed that the global financial cycle drives gross flows and exchange rate movements in most of the countries sampled. Begum (2014) investigated the extent of sterilization of the Bangladesh Bank and found that a long-run relationship exists between NDAs and NFAs. In a study on Pakistan, Khushk, Gilal, \& Taherani (2015) found that the Central Bank partially sterilizes its foreign exchange operation, and for Egypt, Elhendawy (2015) showed the existence of a longrun positive relationship between sterilization and inflation.

In a country-specific study for Algeria, Djedaiet \& Ayad (2017) showed evidence of full sterilization by the Algerian Bank, while in an international study involving some emerging market economies, Ponomarenko (2019) found incomplete sterilization. Arya, Cavoli, \& Onur (2020) examined the relationship between foreign exchange rate and sterilization in 28 emerging market economies and showed that greater fixity of the exchange rate and sterilized intervention can potentially encourage capital inflows. In another study on Nigeria, Nzeh, Nwogwugwu, Uzoechina, Chiedo, \& Anyachebelu (2020) showed that the degree of sterilization is relatively high and significant and that there is also significant but low capital mobility. However, the degree of capital mobility is higher than that reported by Okpanachi (2013). Hoang, Nguyen, \& Nguyen (2020) evaluated the effectiveness of sterilization in Vietnam and found that the State Bank of Vietnam (SBV) has not been able to fully neutralize the impact of inflows on the domestic money supply.

For Botswana, Mannathoko (2020) investigated why monetary policy failed to contain inflation in the 2000 s. Findings showed how a series of policy decisions since 1999 led to a substantial loss of monetary policy autonomy, large offsetting inflows, unsustainable sterilization costs, high inflation, and real exchange rate appreciation. Nzeh et al. (2020) investigated the effectiveness of sterilization policy in controlling money supply and capital inflows in Nigeria. Findings of the study show that the sterilization policy of the Central Bank of Nigeria (CBN) is effective in regulating money supply and depressing capital inflows both in periods of normal capital inflows and in periods of intensive capital inflows. In another study on Nigeria, Jume (2021) assessed the monetary policy response of the CBN to the increases in capital inflows. Results show that the CBN successfully offset $95 \%$ of capital inflows during the period of analysis.

\section{Analytical Framework}

The analytical framework that guided our study is an adaptation of that used by Edwards \& Khan (1985). A major issue in the model is the altering of the conditions for money market equilibrium to include the effects of the sterilization of capital inflows. Through this, the model examines how much the sterilization exercise can put upward pressure on domestic interest rates, thus returning interest rates to the level that existed before the capital inflows episode. One main assumption of the model is that the higher the capital mobility, the more the domestic interest rate will be influenced by external factors, but as capital mobility decreases, the interest rate is driven more by domestic variables. As modified by Cavoli (2005), the model can be explained as follows:

$$
i_{t}=\mathrm{K} i_{t}^{*}+(1-\mathrm{K}) \tau_{t} \quad 0<\mathrm{K}<1
$$

Equation 1 above represents the structural interest rate equation, and it states that the domestic interest rate $\left(\mathrm{i}_{\mathrm{t}}\right)$ is a weighted average of international monetary conditions $\left(\mathrm{i}^{*}{ }_{\mathrm{t}}\right)$ and domestic monetary conditions $\left(\tau_{t}\right)$. In the equation, $\mathrm{K}$ is a parameter that represents a country's level of capital mobility, which lies between zero and one. The exogenous variable, represented by $i^{*}$, is measured by uncovered interest parity (UIP). This is expressed in Equation 2 as follows:

$$
i_{t}^{*}=i t^{f}+\left(e^{e}{ }_{t+1}-e_{t}\right)
$$

Where $t^{f}$ is a foreign currency interest rate and $e_{t}$ is the log of the current period exchange rate expressed in relation to the home price of the external currency. The expected fall in the value of exchange rate in the next time period is represented by $e_{t+1}^{e}$.

In Equation 1, $\tau_{t}$ is the domestic nominal interest rate, which serves as a shadow interest rate. This shadow rate captures conditions of disequilibrium, which come about due to excess demand or supply of money. Cavoli (2005) contended that the shadow rate can be calculated as follows:

$$
\tau_{t}=\varsigma+\Pi_{t+1}^{e}+\vartheta\left(\mathrm{m}_{t}^{d}-m_{t}\right)
$$

Where

$\varsigma=$ full equilibrium real interest rate,

$\Pi^{e}{ }_{t+1}=$ expected future inflation rate,

$\vartheta\left(\mathrm{m}_{t}^{d}-m_{t}\right)=$ a term that captures monetary disequilibrium.

The interest rate $\left(\tau_{t}\right)$ determined domestically can be derived from Equation 3 above. By implication, any excess (shortfall) of money demand $\left(\mathrm{m}^{\mathrm{d}}\right)$ in relation to money supply $\left(\mathrm{m}^{\mathrm{s}}\right)$ will lead to a rise (fall) in the interest rate determined domestically. As observed by Cavoli (2005), money demand is a function of the full equilibrium interest 
rate, expected future inflation, and income $(\mathrm{y})$. The impact of sterilization policy geared towards neutralizing the fallout of reserve inflow enters into the expressions for the money stock, and this can be represented as follows:

$$
\Delta M_{t}=(1+\lambda) \Delta F_{t} \quad \lambda \leq 0
$$

Where

$\lambda=$ the sterilization coefficient, which lies between zero and 1 ,

$\Delta F=$ change in net foreign assets (NFAs).

If we express Equation 4 in $\log$ form, this becomes:

$$
\Delta m_{t}=(1+\lambda) \mathrm{k} \Delta f_{t}
$$

Thereafter, the money stock can be specified as follows:

$$
\mathrm{m}_{t}=\Delta \mathrm{m}_{t}+\mathrm{m}_{t-1}
$$

By substituting Equation 5 into Equation 6, this results in Equation 7, as follows:

$$
\mathrm{m}_{t}=(1+\lambda) \kappa \Delta \mathrm{f}_{t}+\mathrm{m}_{t-1}
$$

As noted by Cavoli (2005), the domestic interest rate can be calculated by substituting Equations 8 and 4 into Equation 3 to find $\tau_{t}$, which is substituted into Equation 1. Thus, deriving the domestic interest rate requires specifying the following equation:

$$
\mathrm{i}_{t}=\phi_{0}+\phi_{1} \mathrm{i}^{*}{ }_{t}-\phi_{2} \Delta \mathrm{f}_{t}-\phi_{3} \mathrm{~m}_{t-1}+\phi_{4} \pi_{t+1}^{e}+\phi_{5} \mathrm{p}_{t}+\phi_{6} \mathrm{y}_{t}
$$

In Equation 8 above, $\mathrm{i}=$ domestic interest rate, $\mathrm{i}^{*}=$ foreign interest rate, $\Delta \mathrm{f}=$ change in reserve inflow, which proxies sterilization policy, $\mathrm{m}=$ money supply, $\pi$ = expected inflation, $\mathrm{p}=$ the price level, and $\mathrm{y}$ is the output growth rate.

\subsection{Model Specification}

Modified from Cavoli (2005), the model that guided this study is specified as follows:

$$
P L R_{t}=\alpha_{0}+\beta T S T R_{t}+\tau X_{t}+\mu_{t}
$$

In this study, we utilized the autoregressive distributed lag (ARDL) bounds cointegration approach developed by Pesaran, Shin, \& Smith (2001). The choice of the model was first informed by the order of integration of the series, which showed an admixture of $\mathrm{I}(1)$ and $\mathrm{I}(0)$, thus suggesting the suitability of the model. Second, it has been noted that whether the series are purely $\mathrm{I}(0)$ or purely $\mathrm{I}(1)$, the bounds testing approach can be applied to the model unlike the conventional cointegration techniques. Beyond these, the strengths of the model were also interesting. One of these strengths is that the ARDL cointegration approach has superior properties in small samples (Pesaran \& Shin, 1999). Also, despite the endogeneity of some of the model's regressors, the model provides unbiased long-run estimates and valid t-statistics (Narayan, 2005; Odhiambo, 2009b). Finally, a simultaneity method of assessing the short- and long-run effects of one variable on the other is guaranteed by the model (Bentzen \& Engsted, 2001). In modelling the ARDL, a dynamic unrestricted error correction model (UECM) can be derived via a simple linear transformation. The UECM integrates the short-run dynamics with the long-run equilibrium without losing any long-run information.

According to Pesaran et al. (2001), the F-test can be applied to determine the presence of a long-run relationship. This is achieved by restricting the coefficients of the lagged level variables $\left(\mathrm{H}_{\mathrm{o}}: \Psi_{1}=\Psi_{2}=\Psi_{3}=\Psi_{4}\right.$ $=\Psi_{5}=\Psi_{6}=\Psi_{7}=0$ ). Pesaran et al. (2001) computed two sets of asymptotic critical values for the ARDL cointegration test. These are the lower bounds critical values $I(0)$ and the upper bounds critical values $I(1)$. If the calculated F-statistic exceeds the upper bound critical value, we conclude in favor of a long-run relationship regardless of the order of integration. If the calculated F-statistic falls below the lower critical values, we cannot reject the null hypothesis of no cointegration. However, if the calculated F-statistic falls between the two critical bounds, inference would be inconclusive.

Generally, the ARDL approach can be specified as follows:

$$
y_{t}=\eta_{1}+y p-1_{t-1}+\ldots \ldots \eta_{p} y_{p-1}+\lambda_{0} x_{t}+\lambda_{1} x_{t-1} \ldots \ldots+\varsigma_{1} x_{t-p}+\mu_{1 t}(10)
$$

Where $t$ represents the trend values denoted as $t=1,2,3, \ldots \ldots . . T$, and $\mu_{\mathrm{t}}$ is the error term, which is independently and identically distributed with a zero mean and constant variance, i.e., $\mu_{t} \approx i i d\left(0, \sigma^{2}\right)$.

Adopting Equation 9 above, and by applying the ARDL approach to cointegration as exemplified in Equation 10, the ARDL that captures our objective is specified in Equation 11 as follows:

$$
\begin{aligned}
& P_{L} R_{t}=\varphi_{0}+\Psi_{1} P L R_{t-1}+\Psi_{2} \text { TSTR }_{t-1}+\Psi_{3} M 2_{t-1}+\Psi_{4} I N F L R_{t-1}+\Psi_{5} \text { EXCHR }_{t-1}+\Psi_{6} \text { WOP }_{t-1}+\Psi_{7} \text { FORINT }_{t-1} \\
& +\sum_{j=1}^{k} \theta_{1 j} \Delta P L R_{t-j}+\sum_{j=0}^{k} \theta_{2 j} \Delta T S T R_{t-j}+\sum_{j=0}^{k} \theta_{3 j} \Delta M 2_{t-j}+\sum_{j=0}^{k} \theta_{4 j} \Delta I N F L R_{t-j}+\sum_{j=0}^{k} \theta_{5 j} \Delta E X C H R_{t-j}+\sum_{j=0}^{k} \theta_{6 j} \Delta W O P_{t-j} \\
& +\sum_{j=0}^{k} \theta_{7 j} \Delta F O R I N T_{t-j}+e_{t i}
\end{aligned}
$$

Where PLR = prime lending rate, TSTR $=$ total sterilization, $\mathrm{M} 2=$ broad money supply (as a proxy for money supply), INFLR $=$ inflation rate, $\mathrm{EXCHR}=$ exchange rate, $\mathrm{WOP}=$ world oil price, and FORINT $=$ foreign interest rate. $\theta_{1}$ to $\theta_{7}$ and $\Psi_{1}$ to $\Psi_{7}$ are the short-run and long-run parameters, respectively. $\Delta$ is the first difference operator, while $k$ is the lag order. The residual $e_{i t}$ is assumed to be normally distributed and white noise. The presence of a long-run relationship implies that we have to specify the error correction model (ECM). With this, we will be able to estimate both the short-run and the long-run coefficients. The ECM is thus specified in Equation 12 as follows: 


$$
\begin{aligned}
& P_{L}=\varphi_{0}+\Psi_{1} P_{t} R_{t-1}+\Psi_{2} \text { TSTR }_{t-1}+\Psi_{3} M 2_{t-1}+\Psi_{4} I_{N F L R_{t-1}}+\Psi_{5} \text { EXCHR }_{t-1}+\Psi_{6} \text { WOP }_{t-1}+\Psi_{7} \text { FORINT }_{t-1} \\
& +\sum_{j=1}^{k} \theta_{1 j} \Delta P L R_{t-j}+\sum_{j=0}^{k} \theta_{2 j} \Delta T S T R_{t-j}+\sum_{j=0}^{k} \theta_{3 j} \Delta M 2_{t-j}+\sum_{j=0}^{k} \theta_{4 j} \Delta I N F L R_{t-j}+\sum_{j=0}^{k} \theta_{5 j} \Delta E X C H R_{t-j}+\sum_{j=0}^{k} \theta_{6 j} \Delta W O P_{t-j} \\
& +\sum_{j=0}^{k} \theta_{7 j} \Delta F O R I N T_{t-j}+\delta E C T_{t-1}+e_{t i}
\end{aligned}
$$

where ECT is the error correction term and $\delta$ is the speed of adjustment.

\subsection{Variables and Data Sources}

We employed monthly series covering the period from January 2010 to March 2021. The prime lending rate was used instead of the official rate because the prime lending rate moves in tandem with economic activities in Nigeria. The monetary policy rate, which is the official rate, is determined by the monetary authorities in their monthly committee meetings, and in most cases these rates are left unaltered for several months. As can be seen in Appendix 1 below, the MPR stayed at 13.5\% from March 2019 through to April 2020. However, the prime lending rate has been fluctuating with different values all through the sample period, indicating that it is more attuned to the dynamics of the economy. In a similar vein, the Bureau De Change (BDC) exchange rate of domestic currency to the dollar was used because of its dynamic nature in the country's economy, being the rate that most economic agents utilize. The international price of the Bonny Light crude oil brand was used because it is Nigeria's crude oil brand. The foreign variables, such as foreign interest rate and world oil price, are included in the model to control for exogenous change in the global economic stance given that Nigeria has integrated into the world economy and is import-dependent and therefore more susceptible to external shocks. Following Kim \& Roubini (2000), the US federal funds rate (FFR) was employed to proxy foreign interest rate. Also, this study followed Vinayagathasan (2013), who employed world oil price as a proxy for expected inflation. Data on all the variables were sourced from the Central Bank of Nigeria Statistical Bulletin, except data on foreign interest rate, which was obtained from the Federal Reserve Bank of St. Louis.

\section{Interpretation of Results and Discussion of Findings}

4.1. Descriptive Statistics

The summary statistics of the variables used in the study are displayed in Table 1 below. The basic characteristics of the data over the study period are displayed in Table 1 and the findings reveal that the variable that exhibited the highest mean is M2 with a value of $20,298,885$ and a standard deviation value of $7,142,150$. This result indicates a spread in the variable. On the other hand, we found that TSTR has the lowest mean of -2467.784 and a standard deviation of 1009555 . TSTR also has the highest range of 23151707 , which implies that over the study period, the variable exhibited some volatility in its trend.

Table 1. Result of Descriptive Statistics.

\begin{tabular}{l|c|c|c|c|c|c|c}
\hline & PLR & TSTR & EXCHR & FORNINT & INFLR & M2 & WOP \\
\hline Mean & 16.23422 & -2467.784 & 273.1013 & 1.577273 & 12.06089 & 20298885 & 5464427 \\
\hline Median & 16.65000 & 34100.37 & 222.9300 & 1.577273 & 11.70000 & 18965534 & 146.2281 \\
\hline Maximum & 19.05000 & 2093049 & 494.7000 & 2.490909 & 18.72000 & 38036535 & 38036535 \\
\hline Minimum & 0.000000 & -10529329 & 151.8500 & 0.500000 & 7.700000 & 10446374 & 75.06000 \\
\hline Std. Dev. & 2.043495 & 1009555 & 115.4450 & 0.533675 & 2.983592 & 7142150 & 12204595 \\
\hline Skewness & -4.380362 & -8.471639 & 0.347535 & -0.005709 & 0.443115 & 0.638267 & 1.820496 \\
\hline Kurtosis & 31.85221 & 89.35932 & 1.568082 & 1.816326 & 2.331946 & 2.694889 & 4.433321 \\
\hline Probability & 0.000000 & 0.000000 & 0.000804 & 0.019430 & 0.031300 & 0.007868 & 0.000000 \\
\hline Sum & 2191.620 & -333150.8 & 36868.67 & 212.9318 & 1628.220 & $2.74 \mathrm{E}+09$ & $7.38 \mathrm{E}+08$ \\
\hline Sum Sq. Dev. & 559.5671 & $1.37 \mathrm{E}+14$ & 1785890 & 38.16446 & 1192.844 & $6.84 \mathrm{E}+15$ & $2.00 \mathrm{E}+16$ \\
\hline
\end{tabular}

In order to ensure that our variables behave well, we carried out a stationarity test of the series. This test is particularly helpful in the choice of the model to be adopted. Both the augmented Dickey-Fuller test (ADF) and the Phillips-Perron test (PP) were used in this study and the results were evaluated based on a $5 \%$ level of significance. The stationarity results in Table 2 below indicate that foreign interest rate exhibited stationarity at level under the ADF test but non-stationarity under the PP test. Also, total sterilization is stationary at level, but other variables are non-stationary at level, that is, they are $\mathrm{I}(0)$. In Table 3 below, after first difference, all the series become stationary, that is, they become $\mathrm{I}(1)$.

\subsection{Tests for Stationarity}

Table 2. Results of Stationarity at Level.

\begin{tabular}{l|c|c|c|c|c}
\hline Variable & ADF t-stat. & PP t-stat. & $\begin{array}{c}\text { ADF Critical } \\
\text { value at 5\% }\end{array}$ & $\begin{array}{c}\text { PP Critical } \\
\text { value at 5\% }\end{array}$ & $\begin{array}{c}\text { Order of } \\
\text { integration }\end{array}$ \\
\hline EXCHR & -2.883239 & -2.883073 & 0.9207 & 0.9319 & Non-stationary \\
\hline FORNINT & $-2.884477^{*}$ & -2.883073 & 0.0345 & 0.4453 & ADF I $(0)$ \\
\hline INFLR & -2.883408 & -2.883073 & 0.4863 & 0.5484 & Non-stationary \\
\hline M2 & -2.883073 & -2.883073 & 1.0000 & 1.0000 & Non-stationary \\
\hline TSTR & $-2.885051^{*}$ & $-2.883073^{*}$ & 0.0022 & 0.0000 & I(0) \\
\hline WOP & -2.883073 & -2.883073 & 0.9823 & 0.9846 & Non-stationary \\
\hline PLR & -2.884477 & -2.883073 & 1.0000 & 1.0000 & Non-stationary \\
\hline Note: Figures with asterisks (*) indicate rejection of the
\end{tabular}

Note: Figures with asterisks (*) indicate rejection of the null hypothesis at the $5 \%$ level. 
Table 3. Result of Stationarity at First Difference

\begin{tabular}{l|c|c|c|c|c}
\hline Variable & ADF t-stat. & PP t-stat. & $\begin{array}{c}\text { ADF Critical } \\
\text { value at 5\% }\end{array}$ & $\begin{array}{c}\text { PP Critical } \\
\text { value at 5\% }\end{array}$ & $\begin{array}{c}\text { Order of } \\
\text { integration }\end{array}$ \\
\hline$\Delta$ EXCHR & $-2.883239^{*}$ & $-2.883239^{*}$ & 0.0000 & 0.0000 & $\mathrm{I}(1)$ \\
\hline$\Delta$ FORNINT & $-2.884665^{*}$ & $-2.883239^{*}$ & 0.0000 & 0.0001 & $\mathrm{I}(1)$ \\
\hline$\Delta$ INFLR & $-2.883408^{*}$ & $-2.883239^{*}$ & 0.0000 & 0.0000 & $\mathrm{I}(1)$ \\
\hline$\Delta$ M2 & $-2.883239^{*}$ & $-2.883239^{*}$ & 0.0000 & 0.0000 & $\mathrm{I}(1)$ \\
\hline$\Delta$ TSTR & $-2.883579^{*}$ & $-2.883239^{*}$ & 0.0000 & 0.0000 & $\mathrm{I}(1)$ \\
\hline$\Delta$ WOP & $-2.578420^{*}$ & $-2.883239^{*}$ & 0.0000 & 0.0000 & $\mathrm{I}(1)$ \\
\hline$\Delta$ PLR & $-2.884477^{*}$ & $-2.883239^{*}$ & 0.0000 & 0.0000 & $\mathrm{I}(1)$ \\
\hline \multicolumn{7}{l|}{ Note: Figures with asterisks $*$ indicate rejection of the null hypothesis at the $5 \%$ level. }
\end{tabular}

As the series show an admixture of $\mathrm{I}(0)$ and $\mathrm{I}(1)$, the ARDL model was chosen to conduct the test of cointegration. In Table 4 below, the F-statistic was compared with both the upper and lower critical values at the $5 \%$ level. The following conditions served as guides: If the value of the $\mathrm{F}$-statistic is greater than the upper critical bound I(1), cointegration exists. On the other hand, if the value of the F-statistic falls below the lower critical bound $\mathrm{I}(0)$, there is an absence of cointegration. The results in Table 4 below show that the F-statistic is 10.82689, which is higher than the upper critical bound (3.61) at the $5 \%$ level of significance. With respect to the findings, it can be concluded that cointegration exists among the series. As a further confirmation of the cointegrating relationship among the variables, the result of the error correction model (ECM) in Table 5 below indicate that the coefficient of the ECM is negative and statistically significant, thus showing that a long-run relationship exists among the variables. The implication of the ECM result is that about $48 \%$ of errors generated in each period is automatically corrected by the system in the subsequent period.

\subsection{ARDL Bounds Test}

Table 4. ARDL Bounds Test Results.

\begin{tabular}{l|c|c}
\hline Test Statistic & Value & K \\
\hline F-statistic & 10.82689 & 6 \\
\hline \multicolumn{3}{|c}{ Critical Value Bounds } \\
\hline Significance & Lower Bound I $(0)$ & Upper Bound I $(1)$ \\
\hline $10 \%$ & 2.12 & 3.23 \\
\hline $5 \%$ & 2.45 & 3.61 \\
\hline $2.5 \%$ & 2.75 & 3.99 \\
\hline $1 \%$ & 3.15 & 4.43 \\
\hline
\end{tabular}

The short-run results indicate that without a lag total sterilization positively impacts the prime lending rate, even though the value of the coefficient is minimal. This result is in line with the a priori expectation of a rising interest rate due to the implementation of the sterilization policy. As the monetary authorities float domestic bonds as a way to neutralize the monetary impact of capital inflows, money supply is reduced, which consequently leads to rising interest rates. A rise in interest rate tends to bring further capital inflows, which may lead to another round of sterilization. Nigeria's case is amplified by the already high interest rate in the country. However, after a lag, findings show that a negative relationship exists between total sterilization and the prime lending rate. We contend that the negative impact of sterilization after some lag could be due to the additional inflows made possible by the increasing interest rate, which is not instantaneously sterilized.

It was noted that the exchange rate exerts a negative influence on the interest rate in Nigeria, though this is not significant. The meaning of this is that as the domestic currency depreciates, the interest rate falls. The macroeconomic impact of a depreciating domestic exchange rate could be the reason for the falling interest rate. As the country's currency weakens, there is a lull in business activities which transmits to the lending rate. Foreign interest rate impacts positively on the domestic interest rate, and a rising foreign interest rate in relation to domestic interest rate means a capital outflow which impacts the domestic interest rate. The drain on liquidity as a consequence of capital outflow means that the interest rate has to rise in order to reverse the outflow. Inflation rate also exhibited a positive impact on interest rate; however, this is not significant. A major concern of the monetary authorities in Nigeria is rising inflation, which constantly puts pressure on them to reduce the interest rate, even in the face of the destabilizing impact of a high interest rate on the macroeconomic environment.

Money supply expectedly impacts the interest rate negatively, which is in line with the dictates of theory. As money supply increases, liquidity in the banking sector rises, which depresses the lending rate. The impact of oil price on the interest rate is mixed. While it negatively impacts the interest rate in the current period, its impact on the interest rate with a lag is negative. The current period result is in line with the a priori expectation that rising oil price leads to increased money supply, which improves liquidity in the banking system and causes the interest rate to fall. This is a typical scenario in Nigeria, where a major source of revenue is from the oil sector. After some periods, however, rising oil price leads to a fall in the interest rate. This could be due to the policy measures put in place, which drain the liquidity in the system, thus resulting in a falling interest rate.

\subsection{Results of the ARDL with Selected $\operatorname{Model}(3,2,0,0,0,0,4)$}

The information in Table 6 shows that all the series exhibited the expected outcomes. The reason for this could be because, in the long-run when all policy constraints are relaxed, the series exhibit their normal behavior. 
Table 5. Short-run Results.

\begin{tabular}{l|c|c|c|c}
\hline Variable & Coefficient & Std. Error & t-Statistic & Prob. \\
\hline $\mathrm{D}(\mathrm{PLR}(-1))$ & -0.152014 & 0.132392 & -1.148204 & 0.2533 \\
\hline $\mathrm{D}(\mathrm{PLR}(-2))$ & 0.217696 & 0.134300 & 1.620967 & 0.1078 \\
\hline $\mathrm{D}(\mathrm{TSTR})$ & 0.000001 & 0.000000 & 15.667895 & 0.0000 \\
\hline $\mathrm{D}(\mathrm{TSTR}(-1))$ & -0.000000 & 0.000000 & -2.304633 & 0.0230 \\
\hline $\mathrm{D}(\mathrm{EXCHR})$ & -0.000447 & 0.002303 & -0.194128 & 0.8464 \\
\hline $\mathrm{D}(\mathrm{FORN} \mathrm{NT})$ & 1.737159 & 0.784671 & 2.213869 & 0.0288 \\
\hline $\mathrm{D}(\mathrm{INFLR})$ & 0.046451 & 0.041861 & 1.109660 & 0.2695 \\
\hline $\mathrm{D}(\mathrm{M} 2)$ & -0.000000 & 0.000000 & -2.039587 & 0.0437 \\
\hline $\mathrm{D}(\mathrm{WOP})$ & -0.000000 & 0.000000 & -2.200915 & 0.0297 \\
\hline $\mathrm{D}(\mathrm{WOP}(-3))$ & 0.000000 & 0.000000 & 1.731812 & 0.0860 \\
\hline $\mathrm{ECM}$ & -0.476992 & 0.093753 & -5.087773 & 0.0000 \\
\hline
\end{tabular}

Table 6. Long-run Results.

\begin{tabular}{l|c|c|c|c}
\hline Variable & Coefficient & Std. Error & t-Statistic & Prob. \\
\hline C & 15.573695 & 1.126301 & 13.827290 & 0.0000 \\
\hline TSTR & 0.000003 & 0.000001 & 4.648281 & 0.0000 \\
\hline EXCHR & -0.000937 & 0.004825 & -0.194278 & 0.8463 \\
\hline FORNINT & 3.641905 & 1.386389 & 2.626901 & 0.0098 \\
\hline INFLR & 0.097384 & 0.085456 & 1.139582 & 0.2568 \\
\hline M2 & -0.000000 & 0.000000 & -2.411642 & 0.0175 \\
\hline WOP & -0.000000 & 0.000000 & -4.631758 & 0.0000 \\
\hline
\end{tabular}

\subsection{Results of Robust Tests}

To further test the reliability of the model, tests were carried out for serial correlation, the normality of the model, and model specification. Under the null hypothesis of the absence of serial correlation, the Breusch-Godfrey serial correlation LM test in Appendix 2 below indicates that we do not have any reason to reject the null, thus showing that the model does not suffer from the problem of serial correlation. Also, under the null hypothesis that the model is well specified, the Ramsey RESET test in Appendix 2 indicates that we cannot reject the null, revealing that the model is well specified. However, the test of normality indicates that the errors are not normally distributed, and this could be attributed to the nature of data set that was employed.

\section{Conclusion and Recommendations}

The aim of this research was to investigate if sterilization policy influences the interest rate in the direction inferred by theory in Nigeria. Theoretically, sterilization policy, through its depressing influence on money supply, is expected to lead to a rise in the interest rate. This assumption was investigated using monthly series over the period from 2010:M1 to 2021:M3 under the ARDL framework. Findings revealed that in the short-run, sterilization policy raises the interest rate in the current period, even though the impact is negligible. However, after a lag, sterilization policy pushes the interest rate to fall but without any visible impact. We also observed that sterilization policy raises the interest rate in the long-run. Additionally, results indicated the existence of a negative relationship between money supply and interest rate in both the short-run and the long-run. The results of the exogenous variables employed in the study show that while foreign interest rates exert a positive influence on the domestic interest rate, oil price influences the domestic interest rate negatively.

With respect to the findings of this study, it is recommended that, in the face of rising and unsustainable capital inflows, different measures should be adopted to cushion the effect of this on the macroeconomic environment. The rising interest rate associated with the implementation of a sterilization policy is an indication that the continuous use of bonds to sterilize inflows is subject to further rounds of increase as foreign investors may avail of the opportunity provided by the rising interest rate to push more short-term capital into the economy. Apart from the fact that this scenario could lead to repeated rounds of sterilization, the fiscal cost of funding the debt thrown up by the floating of the bond has to be considered. It is also recommended that when choosing the interest rate, the Monetary Policy Committee of the CBN should not overlook the impact of exogenous variables, such as foreign interest rates and oil price.

\section{References}

Aghalino, S. O. (2012). Brief but revolutionary: Yar'Adua and the sustainable development of the Niger Delta, Nigeria. Global Advanced Research Journal of History, Political Science and International Relations, 1(6), 144-151.

Aizenman, J., \& Glick, R. (2008). Sterilization, monetary policy and global financial integration. NBER Working Paper No. 13902, National Bureau of Economic Research.

Arya, V., Cavoli, T., \& Onur, I. (2020). Do managed exchange rates and monetary sterilization encourage capital inflows? Plos One, 15(8), e0238205. Available at: https://doi.org/10.1371/journal.pone.0238205.

Begum, M. N. (2014). Reserve accumulation and sterilized intervention in the foreign exchange market in Bangladesh: An empirical analysis. Research Department, Bangladesh Bank, Working Paper Series, WP, 1404.

Bentzen, J., \& Engsted, T. (2001). A revival of the autoregressive distributed lag model in estimating energy demand relationships. Energy, 26(1), 45-55. Available at: https://doi.org/10.1016/s0360-5442(00)00052-9.

Blanchard, O., Adler, G., \& De Carvalho Filho, I. (2015). Can foreign exchange intervention stem exchange rate pressures from global capital flow shocks? IMF Workig Paper, WP/15/159.

Bleaney, M., \& Devadas, S. (2013). Foreign exchange inflows in emerging markets: How much are they sterilized? School of Economics, University of Nottingham Discussion Papers 13/01, University of Nottingham, School of Economics.

Calvo, G., \& Reinhart, C. (1998). The consequences and management of capital inflows: Lessons for Sub-Saharan Africa. Retrieved from http://www.bistandsdebatten.se/wp-content/uploads/2012/10/1998_2-International-Capital-Flows.pdf.

Cavoli, T. (2005). Sterilization, capital mobility and interest rate determination for East Asia. International Macroeconomics and Finance Program Centre for International Economic Studies Discussion Paper No. 0502.

Chung, C., Hwang, J., \& Wang, C. (2014). The effectiveness and sustainability of the sterilization policy in Chin. Economics Research International. Retrieved from https://www.hindawi.com/journals/ecri/2014/509643/. 
Djedaiet, A., \& Ayad, H. (2017). Hard currency inflows and sterilization policy in Algeria: An ARDL approach. Theoretical and Applied Economics, $24(3$ (612), Autumn), 83-96.

Edwards, S., \& Khan, M. S. (1985). Interest rate determination in developing countries: A conceptual framework. Staff Papers, 32(3), $377-403$. Available at: https://doi.org/10.2307/3866804.

Elhendawy, E. O. (2015). Sterilization and Inflation in the long-term empirical evidence from Egypt. Applied Economics and Finance, 2(2), 6878. Available at: https://doi.org/10.11114/aef.v2i2.757.

Hoang, H. T., Nguyen, P. T., \& Nguyen, P. T. (2020). Investigating the effectiveness of sterilization in Vietnam. Journal of Asian Finance, Economics and Business, 7(10), 87-94.

Jume, T. M. (2021). An assessment of the effectiveness of central bank sterilization on capital inflows in Nigeria. CBN Journal of Applied Statistics, 11(2), 201- 230.

Khushk, A. G., Gilal, M. A., \& Taherani, A. (2015). Capital movements and sterilization policies in Pakistan. Grassroots, 49(2), 1-12.

Kim, S., \& Roubini, N. (2000). Exchange rate anomalies in the industrial countries: A solution with a structural VAR approach. Journal of Monetary Economics, 45(3), 561-586. Available at: https://doi.org/10.1016/s0304-3932(00)00010-6.

Lavigne, R. (2008). Sterilized intervention in emerging-market economies: Trends, costs, and risks. Bank of Canada Discussion Paper/Document No.4.

Lee, J. (1997). Sterilizing capital inflows. Economic Issues, IMF No 7.

Ljubaj, L., Martinis, A., \& Mrkalj, M. (2010). Capital inflows and efficiency of sterilization: Estimation of sterilization and offset coefficients. Croatian National Bank Working Paper No. 24.

Mannathoko, I. (2020). Sterilization in Botswana: Cost, sustainability and efficiency. Policy Review No. 690.

Narayan, P. K. (2005). The saving and investment nexus for China: Evidence from cointegration tests. Applied Economics, 37(17), 1979-1990. Available at: https://doi.org/10.1080/00036840500278103.

Nzeh, I. C., Nwogwugwu, U. C., Uzoechina, B. I., Chiedo, O. A., \& Anyachebelu, U. A. (2020). Sterilization policy and capital inflows in Nigeria: A two stage least squares approach. Journal of Economic Studies, 17(1), 1-14.

Odhiambo, N. (2009b). Energy consumption and economic growth nexus in Tanzania: An ARDL bounds testing approach. Energy Policy, 37(2), 617-622. Available at: https://doi.org/10.1016/j.enpol.2008.09.077.

Okpanachi, U. (2013). An assessment of monetary policy response to capital inflows in Nigeria. CBN Journal of Applied Statistics, 3(2), 75-98.

Pesaran, M., \& Shin, Y. (1999). An autoregressive distributed-lag modeling approach to cointegration analysis. Cambridge: Cambridge University Press.

Pesaran, M. H., Shin, Y., \& Smith, R. J. (2001). Bounds testing approaches to the analysis of level relationships. Journal of Applied Econometrics, 16(3), 289-326. Available at: https://doi.org/10.1002/jae.616.

Ponomarenko, A. (2019). Does sterilized foreign exchange interventions cerate money? Bank of Russia Working Paper Series No 40.

Reinhart, C., \& Reinhart, V. (1998). Some lessons for policy makers who deal with the mixed blessing of capital inflows. Munich Personal RePEc Archive (MPR) Paper No. 7123.

Takagi, S., \& Esaka, T. (1999). Sterilization and the capital inflow problem in East Asia. Economic. Economic Research Institute, Tokyo, Japan. Discussion Paper No. 86.

Vinayagathasan, T. (2013). Monetary policy and the real economy: A structural VAR approach for Sri Lanka. National Graduate Institute for Policy Studies, 13(13), 1-31.

Appendix 1. MPR and Prime Lending Rate Figures for 2019-2020.

\begin{tabular}{|c|c|c|c|c|c|c|c|c|c|c|c|c|}
\hline \multicolumn{13}{|c|}{ Prime Lending Rate } \\
\hline Year & Jan. & Feb. & March & April & May & June & July & Aug. & Sept. & Oct. & Nov. & Dec. \\
\hline 2019 & 16.01 & 16.08 & 14.92 & 18.23 & 15.33 & 15.8 & 15.46 & 15.4 & 15.15 & 15.07 & 14.91 & 14.99 \\
\hline 2020 & 14.97 & 15.04 & 14.71 & 14.92 & 14.73 & 15.65 & 12.1 & 11.76 & 11.55 & 11.31 & 11.6 & 11.35 \\
\hline \multicolumn{13}{|l|}{ MPR } \\
\hline 2019 & 14 & 14 & 13.5 & 13.5 & 13.5 & 13.5 & 13.5 & 13.5 & 13.5 & 13.5 & 13.5 & 13.5 \\
\hline 2020 & 13.5 & 13.5 & 13.5 & 13.5 & 12.5 & 12.5 & 12.5 & 12.5 & 12.5 & 11.5 & 11.5 & 11.5 \\
\hline
\end{tabular}

Appendix 2. Robust Test Results.

\begin{tabular}{l|c|c|c}
\hline \multicolumn{4}{c}{ Ramsey RESET Test } \\
\hline T-statistic & Value & df & Probability \\
\hline F-statistic & 7.512990 & 114 & 0.6890 \\
\hline \multicolumn{4}{|c|}{ Breusch-Godfrey Serial Correlation LM Test } \\
\hline F-statistic & 56.44501 & $(1,114)$ & 0.4039 \\
\hline Prob. F $(2,113)$ & 1.051463 & Obs*R-squared & 2.393366 \\
\hline
\end{tabular}

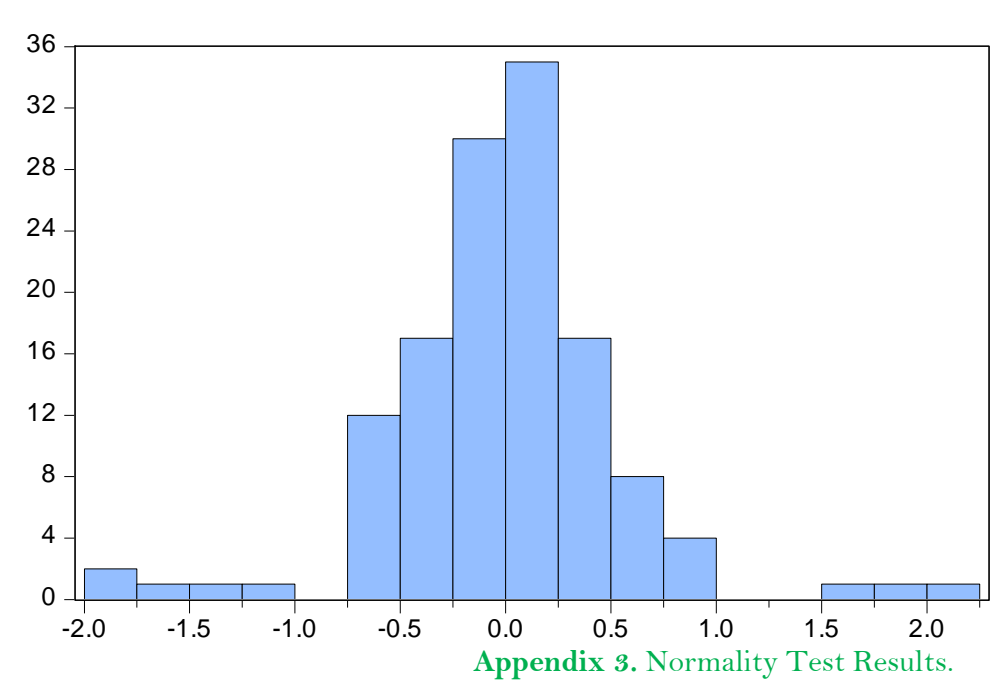

Series: Residuals

Sample 5135

Observations 131

Mean

$6.52 \mathrm{e}-15$

Median $\quad 0.017838$

Maximum $\quad 2.189281$

Minimum $\quad-1.917740$

Std. Dev. $\quad 0.561729$

Skewness $\quad 0.034841$

Kurtosis $\quad 6.998872$

Jarque-Bera $\quad 87.31060$

Probability $\quad 0.000000$

Asian Online Journal Publishing Group is not responsible or answerable for any loss, damage or liability, etc. caused in relation to/arising out of the use of the content. Any queries should be directed to the corresponding author of the article. 